\title{
CALCULATION AND SPATIAL DISTRIBUTION OF CAPITALIZATION RATES IN THE SELECTED SEGMENT OF REALITY PROPERTIES
}

\author{
Eva ARDIELLI ${ }^{5}$, Jiři ARDIELLI ${ }^{6}$, David SLAVATA ${ }^{7}$ \\ VSB-Technical Univerzity of Ostrava \\ Tieto Czech, s.r.o. \\ VSB-Technical Univerzity of Ostrava
}

\begin{abstract}
The process of real property valuation by usage of income approaches is significantly affected by capitalization rate. This article deals with problematic of the capitalization rate determination in the real estate segment of apartments in the Ostrava city. It primarily aims to calculate the level of gross capitalization rate according to different urban localities of Ostrava, for various sizes of apartments, as well depending on the type of apartment ownership. The analysis of the real estate market is an important part of the research. It is focused on the offer of apartments from the perspective of market apartments for sale and also of market apartments for rent. The analyzed and calculated spatial values distributions are consequently processed into cartographic outputs.
\end{abstract}

\section{KEY WORDS}

Apartments, capitalization rate, income approaches, Ostrava, real estate market.

\section{JEL CLASSIFICATION}

$R 310, R 210$

\section{INTRODUCTION}

Apartment market represents an important segment of the real estate market, which enjoys great popularity among professionals and the public. It is also the subject of frequent scientific studies and analyses, for example Parli (2008), Komárek and Kubicová (2011) or Mills, Parli and Anthony (2008). It is possible to describe, compare and analyze the apartments and their market price based on many attributes, that may include the physical characteristics of the apartment (internal layout, size, equipment, state, type of building structure, location in the floor) as well as the location of the

\footnotetext{
${ }^{5}$ Correspondence address: Eva, Ardielli, Ph.D.; eva.ardielli@vsb.cz: VSB-Technical University of Ostrava, Faculty of Economics, Sokolská 33, 702 00, Ostrava, Czech Republic

${ }^{6}$ Correspondence address: Jiří, Ardielli, Ing.; jiri.ardielli@tieto.com: Tieto Czech s.r.o., 28. října 3346/91, 702 00, Ostrava, Czech Republic

${ }^{7}$ Correspondence address: David, Slavata, Ph.D.; david.slavata@ vsb.cz: VSB-Technical University of Ostrava, Faculty of Economics, Sokolská 33, 702 00, Ostrava, Czech Republic
} 
flat (in terms of the attractiveness of the location or the availability of civic amenities). A significant factor is also the localization of the apartment by region, see Mackmin (1999) or Gelbtuch (2011).

The aim of this paper is to evaluate the gross capitalization rates by usage of the standard methods, as described for example in Bradáč, Krejčíř and Scholzová (2012) or Zazvonil (2009), for each category of apartments located in the City of Ostrava and also to analyse the different values of gross capitalization rate in different districts of the city.

Capitalization rate generally represents the costs (interests) for borrowed capital. It is also very sensitive item at the calculations of yield values of properties. The estimation of yield value of the property is practically often applied not only at valuation praxis but also in the investment environment, in a situation when the investor decides about the effectiveness of the investment (Douglas and Osborn, 2014). The outputs of the research may contribute primarily in this field to the more accurate final result in income valuation application. In particular, this article discusses the findings of gross capitalization rates based on locations and types of properties in the Ostrava region in relation to the theory of property valuation. It is based on data obtained by analysis of market prices and market rents of apartments. It aims to refine the value of capitalization rate to calculate the yield value of the property in individual locations in Ostrava and to investigate in detail the gross capitalization rate in selected districts from the perspective of the size and ownership of the apartments.

The structure of the article is devoted into introduction and theoretical statement, where attention is paid to the importance of capitalization rate specification and the possibilities of its determination. The results of empirical research then evaluate the selected segment of reality properties in Ostrava region from the spatial and real estate market aspects. This is the unique evaluation of the capitalization rates in the real estate segment of apartments focusing in detail on Ostrava region. The research and data obtaining is based on data mining techniques and software for online data gathering.

\section{STATEMENT OF A PROBLEM}

The estimation of real estate property values is a complex process that is influenced by various factors as the physical characteristics of real estates, local equipment or political and economic factors as stated in Melanda, Hunter and Barry (2016) or Janasová, Ardielli and Slavata (2014). Theory of valuation describes the basic approaches used in real estate valuation. One of them is represented by income approach. The basis of this method is the transformation of future income to present value by usage of given level of capitalization. Capitalization rate is defined for these purposes in International Valuation Standards, see IVSC (2007). Capitalization rate is the price for loan capital, which is expressed either as a percentage $(\%)$ or in centesimal form, as stated by Maříková and Mařík (2001). The capitalization rate is very sensitive item in the calculation process of yield values. The level of capitalization rates is significantly influenced by risk of the investment. Between the degree of risk and the capitalization rate exists direct relationship. The higher is the yield on the investment, the higher is the risk of possible losses on investments. In principle, the surest investments are investments in banking institutions. At the moment the appreciation rate on deposits is usually $0.1 \%-0.5 \%$ per annum. Investment in property from this sight of view belongs to one of the surest.

To determine the real yield from the saved capital, capitalization rate is usually calculated from the achieved interest rate (nominal interest rate), which is adjusted for annual inflation (real interest rate) based on the Fisher equation, fee formula (1): 


$$
i r=\frac{q n}{q i},
$$

where $i_{r}-$ is the real interest rate,

$q_{n}$ - is the nominal interest,

$q_{i}-$ is interest of the annual inflation rate.

Determination of the capitalization rate for purpose of the valuation of real estate has its own specifics. In particular, the nominal value of the property, measured in replacement cost, is rising with inflation of value of construction works, and it implies that the investments in real estates are immune to inflation. Also the rent inflation nominally usually grows and in case of eventual sale grows also the entirely property value. For this reason, the effect of inflation is not considered by usage of income approaches. Another distinguishing feature is the higher risk of investments in real estates. The risk-free interest rate (nominal interest rate) is actually max $1 \%$ while the expected return on real estate may be much higher.

The determination of the capitalization rate is carried out by comparison in the presented research. This method is specified for example by Zazvonil (1996). The comparative methods are used often by real property valuation and they are used in two concepts. On one hand the comparison is the basic valuation approach that is based on direct comparison of comparable properties in real time. Here is assumed that the comparable property should have also comparable price (comparative method). In the second concept is comparison only one the sub-part of the basic valuation approaches. E.g. Income approaches compare rents and sales prices, within the cost approaches are measured individual cost items by comparing prices of materials and labor. The basic principle of comparative methods can be expressed by the following mathematical notation (2):

$$
P H=\frac{1}{n} \times \sum_{i=1}^{n} R C_{i} \cdot K a
$$

where $P H-$ is value of the thing determined by comparison,

$n-$ is the number of things that have the same characteristics as the valued thing for which we know the realized price,

$R C i$ - is realized price for the $\mathrm{i}$-th property,

$K a-$ is the coefficient of comparison expressing the a-th characteristic of the thing.

Calculation of capitalization rate can be done then in the following ways:

- In case of approximately same objects the capitalization rate (centesimal) is determined by the simple arithmetic average from the relationship: achieved annual profit / achieved sales price,

- for unequal objects, but otherwise comparable objects (buildings) could be used a weighted average, where the profit from a larger object is reflected by greater weight.

The value of the capitalization rate is determined by comparison with similar property types; see Bradáč et al (2009). It is based on knowledge of the realized normal price (sale price) and the net income from the rental property. Specifically, the capitalization rate is determined based on the great number of records on real estates in the statistical file (database) as the arithmetic average of the realized normal prices of properties and annual net income of these objects according to equation (3):

$$
R=\frac{1}{n} \times \sum_{i=1}^{n}\left(\frac{C V_{i}}{C O B_{i}}\right),
$$

where $R-$ is the capitalization rate, 
$n-$ is the number of realized sales,

$C V-$ is the net annual income,

$C O B-$ is the price of the object.

Above mentioned input attributes are taken from the database of properties (realized sale prices of the properties and realized annual net income of the properties). From this reason it is necessary to monitor these attributes on the real estate market long-term and to record them clearly into the database.

The capitalization rates increase generally with the increasing risk of the investment. The real estate risks are associated primarily with the location in the wrong location, such as the location of the property in less attractive locality or flood zone (Ardielli and Janasová, 2011).

In case of the absence of relevant data it is possible to use other methods of capitalization rate calculation, e.g. the modular system. The core is determined by safe type of investment in the financial market and superstructure by the risk premium, which is the sum of the risks. For further details see Maříková and Mařík (2001 and 2007). It is also possible to compare the nominal level of capitalization with data from Annex of the Decree by Ministry of Finance (No. 199/2014 Coll). In the document are given the concrete values of capitalization rates by type of construction for the valuation of property by income approaches.

In practice, it may be encountered with other possible methodologies for estimating the capitalization rate, which may be based on practical experiences or on exact calculations. It is clear, however, that the capitalization rate has a significant impact in the determination of the yield value of the property and therefore it is necessary to pay attention to its proper determination.

\section{METHODS}

Applications of outputs and findings of this research are seen in the specification of the capitalization rate for the correct calculation of the yield value of the property according to equation (4):

$$
\begin{aligned}
& V H=\frac{C V}{R}, \\
& \text { where } \begin{array}{l}
V H-\text { is the yield value of the thing, } \\
C V-\text { is the net rental income, }
\end{array} \\
& \quad R-\text { is the capitalization rate centesimal. }
\end{aligned}
$$

The optimal way to calculate the capitalization rate is to determine the level of capitalization rate freom the purchase prices of similar properties in comparable locations and their rent prices Bradác et al. (2009). This method was used in the presented paper. The main prerequisite for the usage of this method was the existence of the required database of comparable properties, knowledge of their market prices, rental prices and the credibility of the reported data.

In the presented research was distinguished net and gross capitalization rate. Net capitalization rate is determined from knowledge of the gross annual revenues, annual expenses and also the selling prices of real estate. The research focused on determination of the gross capitalization rates. In this way was eliminated the detection of costs associated with property maintenance. Due to the fact that for the calculation of the gross capitalization rate the standard selling prices are needed, within the database were observed the duration periods of the properties sales and final prices corresponding 
with the realized sales prices. A secondary product of this sub step was the analysis of the marketability of the properties by type and location in the city of Ostrava. An indicator of the marketability is the duration of the offer of certain property. This value also indicates the liquidity of real estate.

Offer prices are usually taken as estimations of market prices for each property. The offer price is therefore usually adjusted by the coefficient of reduction on the price source (kZC). This coefficient compares discrepancy between market prices and offer prices. In the current state, the value of the coefficient of reduction on price source $\mathrm{kZC}$ is 0.85 . This value comes from literature, but it is inaccurate and particularly because there are not distinguished the different types of real estates and various locations of real estate. More specifically clarifies Cupal, see Cupal (2011).

In this research, however, was monitored the entire time series of individual advertisements on reality websites, respectively updates of this advertisements. Update of advertisements contained mainly the price adjustment. For advertisement with sales that have been posted (updated) for up to 90 days (most ads), the selling price of apartments decreased on average by $4.03 \%$. Ads with rents were in the vast majority published (or updated) for up to 60 days until their first publication. During this reported period, the average rental price decreased on average by less than $3 \%$. The evaluation was then calculated by taking the offer price of the last update of each ad, which is presumed as the realized sale price or the price very close to it. Last updated offer prices (before the disappearance of the advertisement from the websites) for each property were therefore treated as sale (market) prices. Sale prices of real estates were then compared with the required rents for similar properties located in the same area and property of the same type (category $1+1,2+1$, etc.).

\subsection{Data gathering}

The important prerequisite for the implementation of the research was the provision of continuous and automated monitoring of apartment prices and rents in Ostrava. This input data were collected by usage of the automated process. The result of this data monitoring and gathering was the database of rentals and sales.

Data of market prices and rents were recorded over a period of two years from the 1st of February 2012 to 31 st of January 2014. As the data source served the server sreality.cz. In the database was processed a total of over 16000 records relating to the bid prices of apartments and over 15000 records relating to requested rent price of apartments in the city of Ostrava. Data included all updates of monitored ads registered during the reporting period. This means that for the given property the advertisement has been stored in the database repeatedly, up to $16 \mathrm{x}$ depending on how often the ad was updated. The gradual changes of the property in advertisements contained mainly the price changes. The resulting number of unique ads, i.e. ads that identify the property regardless of the number of updates is therefore lower - less than 7000 unique ads for the sale database and nearly 11000 unique ads for the rent database.

This process of monitoring of ongoing updates ensured the obtaining of input data for the analysis and getting insights about the movement of prices and rents of apartments from the submission of the advertisement till its clearing (sell or rental was finished). The prices used for the calculation of capitalization rates are the bid prices, however they converge in the time series to the real sale/rent prices. For this reason it was not used the coefficient of reduction on the price source, which is recommended by Bradáč et al. (2009) in case of usage of data from advertisements. In case if the price of the real estate would be taken without the monitoring of time series of the ads, this coefficient would be appropriate to adjust the price to the sale price. Prices quoted in the database are therefore taken as sale prices, or prices very close to the price of the realized sale or rent. 


\subsection{The database structure of the sales and rental}

For the reliable processing of the database and for the calculations, it was necessary to design an appropriate database structure, in which the input data will be stored. Data must be clearly recorded and contain the unique identifier that ensures easy navigation in the database, and uniqueness of each record. Data structure and domain attributes were based on data provided by source, see SREALITY (2016).

Database structure:

- ID (a unique identifier of the record)

- DATE

- TIME

- LINK (unique identifier of ad - groups of updated records)

- PRICE

- AREA $\left(\mathrm{m}^{2}\right)$

- SIZE (type / category of apartment $1+\mathrm{kk}, 1+1, \ldots$ )

- CONSTRUCTION (panel, brick, ...)

- FLOOR

- OWNERSHIP (cooperative, private, other)

- CADASTRE

- STREET

In terms of the geographical location the data records contained the municipality name and street. One possibility of the geographic categorization was to compare records with city price-map, which reflects the lucrativeness of land within the city in terms of set criteria. Another option was to use the cadastral territory map, for further details see Dokládalová (2005). This option was chosen for further application. The geolocation of property was carried out with regard to the administrative districts. For the purposes of geolocation on districts level (or cadaster) each entry was assigned the name of cadaster and street name. In the districts where were detected high number of ads was conducted geolocation accuracy with the resolution on cadastral level.

\subsection{Data preparation for evaluation}

The database has been cleared from data with zero price, unrealistic price, from record without entered street and records located outside Ostrava (removal of 1212 records of sales). After aggregation of records belonging to one ad (aggregation of updates) remained the resulting number of unique ads for sales on 6636 entries, see tab. 1.

\section{Table 1 Statistics of sale records}

\begin{tabular}{||c|c||}
\hline PROCEDURE OF DATA CLEANING & NUMBERS \\
\hline Records totally & 16116 \\
\hline Zero price & 357 \\
\hline Non-real price & 63 \\
\hline Without street & 656 \\
\hline Outside Ostrava & 136 \\
\hline Cleanup data & 14904 \\
\hline Data after aggregation & 6636 \\
\hline
\end{tabular}

(Source: Authors' processing) 
Similarly, the number of unique ads for rent was 10418 records. For the purpose of obtaining of sales prices (i.e. prices very closed to sales prices) and rent prices, was created the database of final prices, which included only the most recent records of individual advertisements for the given property which were derived from the time series of tracked ads.

\section{PROBLEM SOLVING}

The results of the research are divided into two outputs. In the first part there are evaluated the ads for the both options - offer of apartments to sale and offer of apartments to rent. In the second section there are evaluated the capitalization rates in the locations of Ostrava.

\subsection{Evaluation of the ads - offer of apartments to sale}

Almost two-thirds of ads (4 103) were made only once without subsequent updates, and then were removed from the offer. The remaining one-third of ads was updated 1-11 times. Only a minority of ads was updated more than 12 times. The exact number of advertisements and the number of updates are shown in Table 2.

Table 2 Updates of ads - sales

\begin{tabular}{||c|c|c|c|c|c|c|c|c|c|c|c|c||}
\hline \hline NO. OF UPDATES & 0 & 1 & 2 & 3 & 4 & 5 & 6 & 7 & 8 & 9 & 10 & $>10$ \\
\hline Quantity of ads & 4103 & 877 & 439 & 310 & 208 & 180 & 144 & 173 & 115 & 54 & 15 & 18 \\
\hline
\end{tabular}

(Source: Authors' processing)

Number of ads occurrences by size of apartment (number of rooms) is shown in Figure 1. The most frequently offered were apartments 2+1, (total of 2491 occurrences), followed closely by apartments $3+1$ (total of 2431 occurrences).

\section{Figure 1 Apartments to sale by number of rooms (category of apartments)}

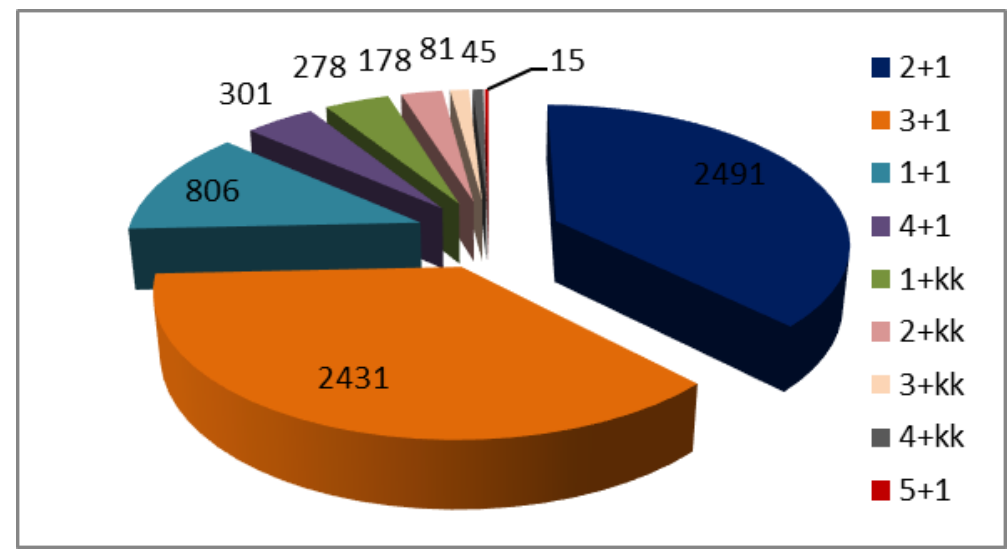

(Source: Authors' processing)

Great apartments 5+1, 5+kk and 6+1, and other atypical apartments were advertised during the monitored period only in a very small number ( 15 or less occurrences). The area of apartments offered to sale ranged from $17 \mathrm{~m}^{2}$ to $402 \mathrm{~m}^{2}$. 
In terms of occurrence by locality there were most frequently on real estate web-sites advertised apartments to sale in the district of Poruba, Zábřeh and Moravian Ostrava, as indicated by the area chart in Figure 2.

Figure 2 Apartments to sale by location

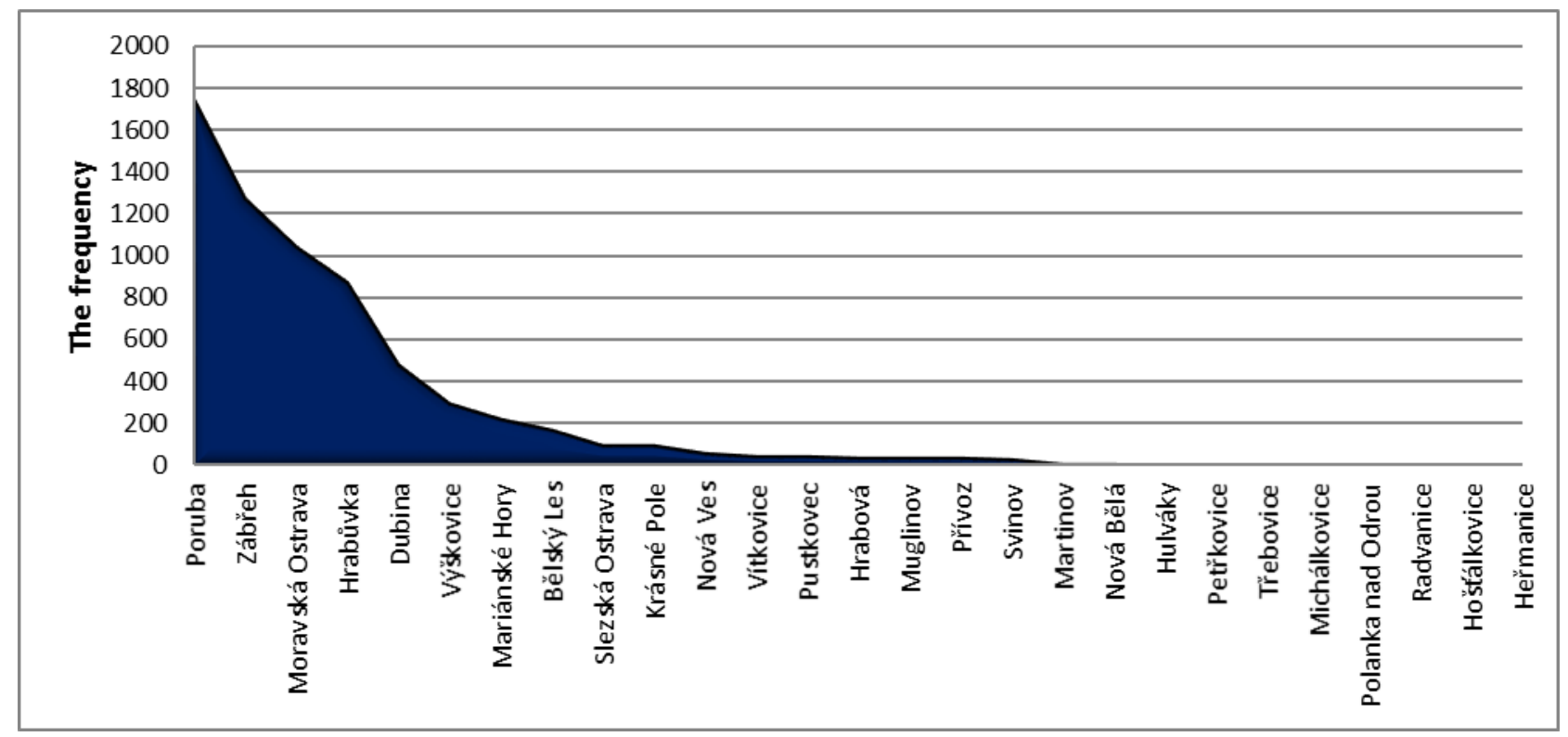

(Source: Authors' processing)

Conversely, in districts without extensive settlement structures, such Heřmanice, Hošt'álkovice, Radvanice, Polanka nad Odra, Michálkovice, Trebovice or Petřkovice, was stored the minimum of records. The exact frequency of ads in different locations in Ostrava is summarized in Table 3. There are listed seven districts (or cadastral areas) with the most frequent occurrence of advertisements.

\section{Table 3 Apartments for sale by location}

\begin{tabular}{||c|c||}
\hline \hline THE CITY DISTRICT & FREQUENCY \\
\hline Poruba & 1745 \\
\hline Zábř́h & 1271 \\
\hline Moravská Ostrava & 1039 \\
\hline Hrabůvka & 871 \\
\hline Dubina & 479 \\
\hline Výškovice & 294 \\
\hline Mariánské Hory & 221 \\
\hline
\end{tabular}

(Source: Authors' processing)

The next monitored criterion was the apartment's ownership. Apartments to sale were sorted in three kinds on private, cooperative and others. $59 \%$ of all apartments were in cooperative ownership and $41 \%$ of apartments in private ownership. Other ownership contained only 22 apartments, see Figure 3. 


\section{Figure 3 Apartments to sale by type of ownership}

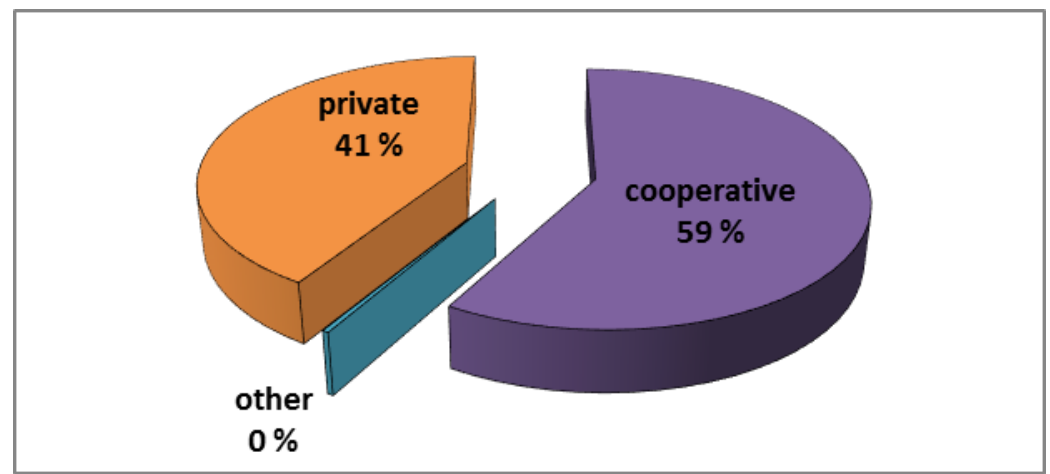

(Source: Authors' processing)

\subsection{Evaluation of the ads - offer of apartments to rent}

About $75 \%$ of adverts of the apartments offered to rent were filed only once without subsequent updates (total of 7 824), and then were removed from the offer. The remaining about quarter of advertisements was updated 1-4 times. Only a negligible part of the ads were updated more than 8 times. The exact frequency of ads for each update is summarized in Table 4.

\section{Table 4 Updates of ads - rentals}

\begin{tabular}{||c|c|c|c|c|c|c|c|c|c|c|c|c|}
\hline \hline NO. OF UPDATES & 0 & 1 & 2 & 3 & 4 & 5 & 6 & 7 & 8 & 9 & 10 & $>10$ \\
\hline Quantity of ads & 7824 & 1405 & 641 & 343 & 104 & 38 & 26 & 12 & 13 & 4 & 1 & 5 \\
\hline
\end{tabular}

(Source: Authors' processing)

The offer of apartments to rent in terms of the size of apartments by room number was wide, including apartments from size $1+1$ to size 7+1, atypical and other variants with kitchenette (the $+\mathrm{kk}$ apartments). Graphically is the situation shown in Figure 4.

Figure 4 Apartments for rent by number of rooms (category of flats)

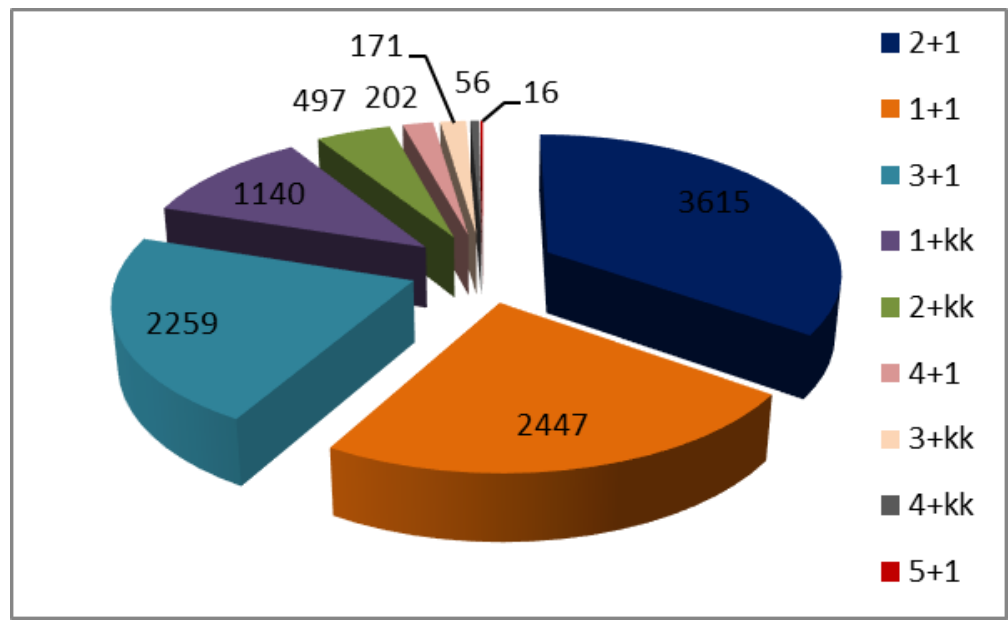

(Source: Authors' processing) 
Most offered apartments were apartments $2+1$ (total of 3615 records). Next followed apartments were type $1+1$ (2447 records) and 3+1 (2431 records). Big apartments of type 5+1, 5+kk, 6+1, $6+\mathrm{kk}, 7+1,7+\mathrm{kk}$, and other atypical apartments were advertised only in very low numbers (16 and under). The area of apartments to rent ranged from $15 \mathrm{~m}^{2}$ to $260 \mathrm{~m}^{2}$.

According to the web-sites were the most numerous real estate advertised to rent located in the district of Poruba, Moravian Ostrava and Zábřeh. This corresponds with the situation of apartments to sale. Conversely, the lowest number of entries was registered in locations with vast family houses such as Hrušov, Polanka nad Odra, Lhotka, Bartovice or Proskovice. Graphically, the frequency of bids is shown in Figure 5.

\section{Figure 5 Apartments to rent by location}

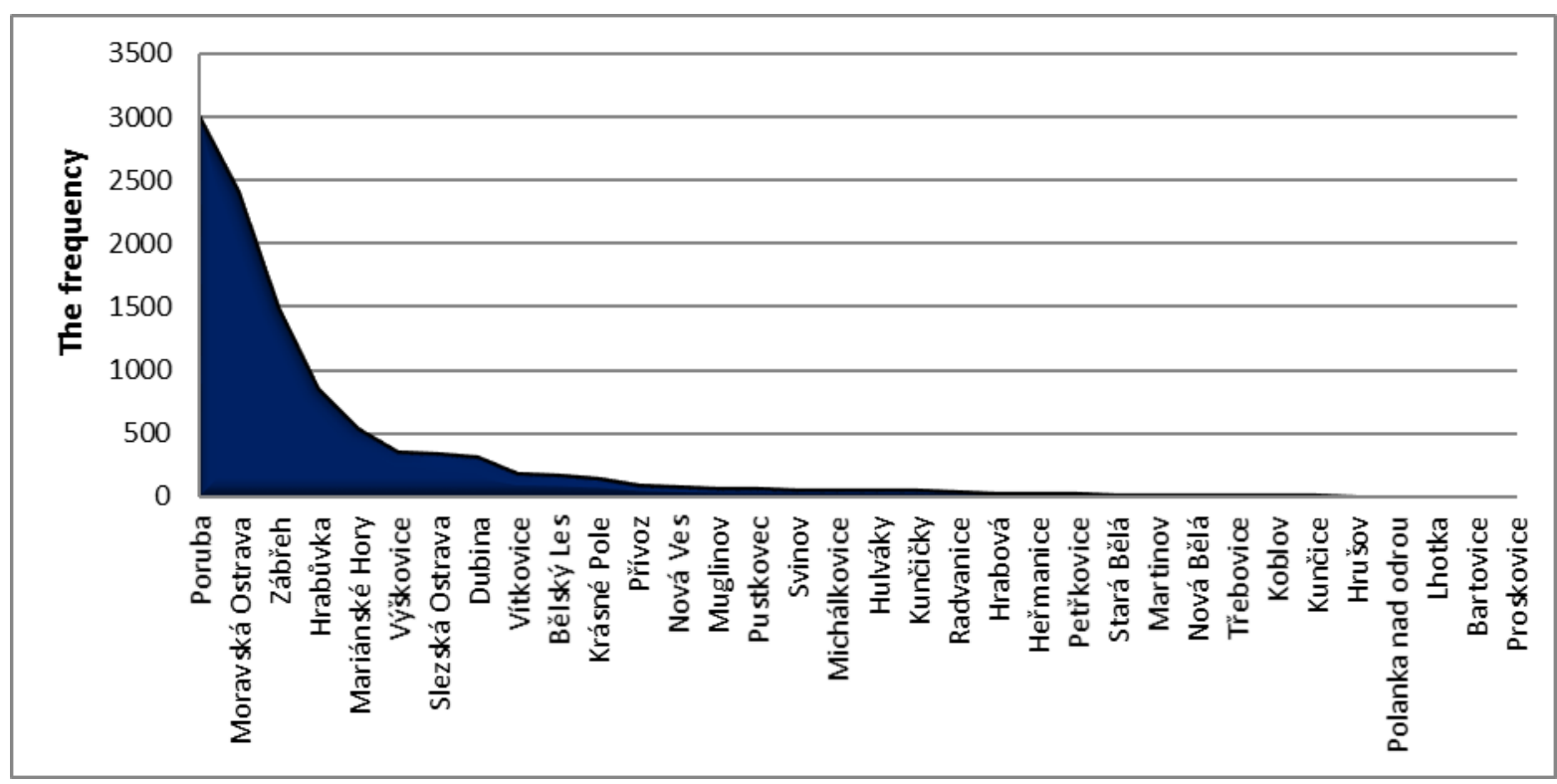

(Source: Authors' processing)

The exact frequency of ads in different locations of Ostrava is summarized in Table 5. Here are specified 7 districts (or cadastral areas) with the most frequent occurrence of advertisements.

\section{Table 5 Apartments to rent by location}

\begin{tabular}{||c|c||}
\hline THE CITY DISTRICT & FREQUENCY \\
\hline Poruba & 3008 \\
\hline Moravská Ostrava & 2409 \\
\hline Zábř̀h & 1487 \\
\hline Hrabůvka & 847 \\
\hline Mariánské Hory & 530 \\
\hline Výškovice & 355 \\
\hline Slezská Ostrava & 338 \\
\hline
\end{tabular}

(Source: Authors' processing)

In the case of apartments to rent the apartments were also divided in terms of ownership. The result was different than in case of apartments to sale. $55 \%$ of all apartments were in private ownership 
and $31 \%$ were in cooperative ownership. There were also strongly represented the category of apartments owned by "other" - (14\%), see Figure 6

Figure 6 Apartments to rent by type of ownership

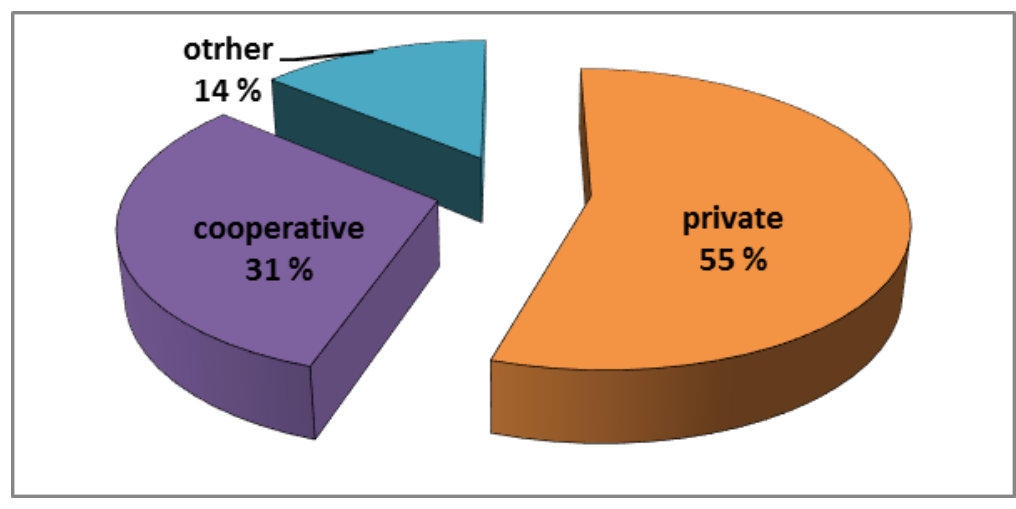

(Source: Authors' processing)

\subsection{Specification of capitalization rates}

The outcome of the research was to determine the level of gross capitalization rates in Ostrava districts. In Fig. 7 is depicted the distribution of the gross capitalization rates of apartments by individual districts. Gross capitalization rates in most Ostrava districts range from 4.1 to $8.0 \%$.

\section{Figure 7 Gross capitalization rate of apartments in individual districts}

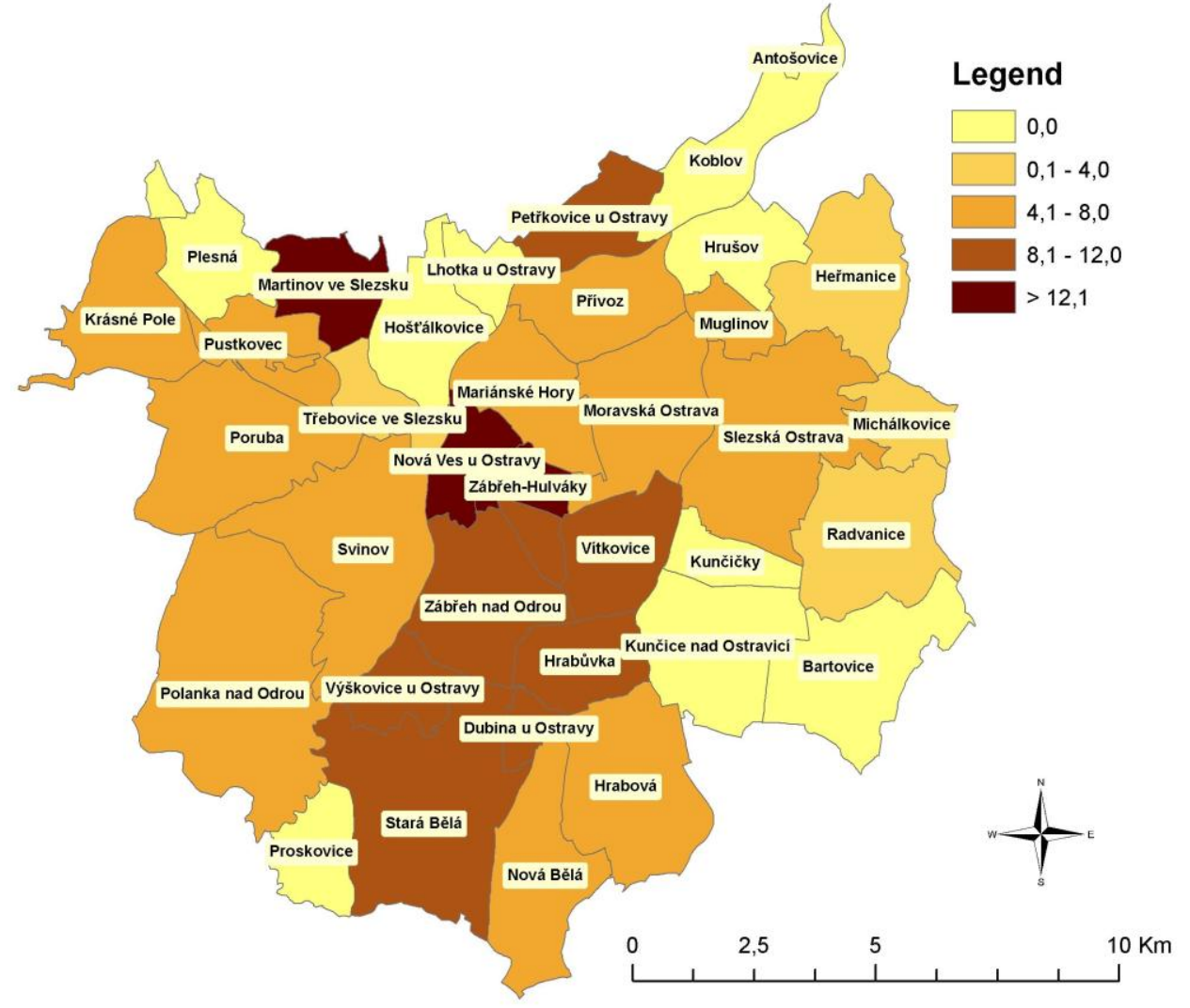

(Source: Authors' processing) 
In some districts of Ostrava couldn't be calculated the capitalization rate because of the insufficient data for evaluation (e.g. Plesná, Koblov, Antošovice, Proskovice, Bartovice, Lhotka u Ostravy). These were mainly the districts in which the area is made up of mostly single-family houses, so that there was only limited offer of apartments to rent, and limited or non-existent offer of apartments to sale.

In Table 6 is shown the level of gross capitalization rate by size of the apartment. The calculation was performed regardless of the location of the apartment within Ostrava for apartments in the size category $1+1,2+1,3+1,4+1,5+1$ and their variations with kitchenette.

\section{Table 6 Gross capitalization rate by size of apartment}

\begin{tabular}{||c|c||}
\hline FLAT SIZE & GROSS CAPITALIZATION RATE (\%) \\
\hline $1+1$ & 11,4 \\
\hline $1+\mathrm{kk}$ & 11,5 \\
\hline $2+1$ & 9,5 \\
\hline $2+\mathrm{kk}$ & 8,3 \\
\hline $3+1$ & 8,5 \\
\hline $3+\mathrm{kk}$ & 4,8 \\
\hline $4+1$ & 8,2 \\
\hline $4+\mathrm{k}$ & 5,0 \\
\hline $5+1$ & 8,1 \\
\hline
\end{tabular}

(Source: Authors' processing)

For apartments in the size category $1+1,2+1,3+1,4+1,5+1$ and variations of apartments with kitchenette, was done the calculation of gross capitalization rates by the resolution of parameter the type of ownership, see tab. 7.

Table 7 Gross capitalization rate by size of apartment and type of ownership

\begin{tabular}{||c|c|c||}
\hline FLAT SIZE & $\begin{array}{c}\text { GROSS CAPITALIZATION } \\
\text { RATE OF PRIVATELY } \\
\text { OWNED FLATS }(\%)\end{array}$ & $\begin{array}{c}\text { GROSS CAPITALIZATION } \\
\text { RATE OF FLATS IN } \\
\text { COOPERATIVE } \\
\text { OWNERSHIP (\%) }\end{array}$ \\
\hline $1+1$ & 11,0 & 12,0 \\
\hline $1+\mathrm{kk}$ & 9,5 & 13,4 \\
\hline $2+1$ & 9,3 & 10,6 \\
\hline $2+\mathrm{kk}$ & 6,6 & 13,3 \\
\hline $3+1$ & 7,8 & 10,0 \\
\hline $3+\mathrm{kk}$ & 4,7 & 6,6 \\
\hline $4+1$ & 6,6 & 9,4 \\
\hline $4+\mathrm{kk}$ & 3,2 & 10,2 \\
\hline
\end{tabular}

(Source: Authors' processing) 


\section{CONCLUSIONS}

In the valuation practice in the Czech Republic, there is in determining of the value of real estate normally operated with the capitalization rate. The basis for the calculation by the yield method presents the net capitalization rate. However, a significant attribute represents also the gross capitalization rate. For its calculation is not necessary to quantify the costs associated with holding of the property.

For the purpose of the quick decisions of investors, and also as a tool for appraisers and experts, the detailed mapping of the gross capitalization rate for the segment of apartments in Ostrava was made. Gross capitalization rate was calculated for each size category of apartments and for both types of ownerships and also for individual locations of Ostrava.

The research aimed to ensure sufficient data sample for subsequent analysis of the market prices and rents of apartments. The analysis of automated obtained data has shown the sufficient number of both sales and rental ads. Extensive sample of data allowed subsequent analysis of prices on several levels - by category of apartment, by ownership type and by location. In addition, ensuring of the monitoring of time series of ads, respectively their updates, allowed the analyzes of the marketability of apartments, the frequency of updates, price changes, respectively price change from the first administration of the ad to its latest update.

The presented article described the possibility of evaluation of the level of capitalization rate. In the practical part dealt with the practical setting in the city of Ostrava from the perspective of the individual districts and also from the perspective of the individual categories of apartments. Gross capitalization rate in Ostrava districts ranged from 1.8 to $15.9 \%$, the most common was between 4.1 to $8.0 \%$.

The comparison of the gross capitalization rates of apartments by type of ownership implied that the higher level of gross capitalization was reported in case of apartments in cooperative ownership than in privately owned apartments. Gross capitalization rate wasn't less than $4.0 \%$ for apartments in cooperative ownership in any district of Ostrava.

In terms of the locality the highest level of gross capitalization rate was observed in ZábřehHulváky and Nova Ves near Ostrava. High level of gross capitalization was calculated in the locality Ostrava-Jih, which is directly connected with aforementioned city districts and forms the comprehensive area of Ostrava with the highest gross capitalization rates of apartments in Ostrava. Ostrava-Jih consists of cadastral areas Dubina, Hrabůvka, Výškovice, Zábřeh nad Odrou. It is the most populous district of Ostrava with dense residential development, which is home to about the third of city residents.

This paper was supported within Operational Programme Education for Competitiveness (Project No. CZ.1.07/2.3.00/20.0296).

\section{REFERENCES}

Ardielli, J \& Janasová, E. (2011) Possibilities of Analyzing of Real Estate's Prices in Flood Areas. In International Multidisciplinary Scientific GeoConference-SGEM: vol. 3, pp. 1129-1136, ISSN 1314-2704.

Bradáč A. et al. (2009) Teorie oceňování nemovitostí Eight Edition. Brno: CERM ISBN 978-807204-630-0. 
Bradáč, A. \& Krejčíŕ, P. \& Scholzová, V. (2012) Úřední oceňování majetku 2013, 1st edition. Brno: CERM, ISBN 978-80-7204-825-0.

Cupal, M. (2011) Koeficient redukce na zdroj ceny v komparativní metodě oceňování nemovitostí. Soudní inženýrství, vol. 22, no.: 1, pp. 8-21.

Česká republika. Vyhláška Ministerstva financí č. 199/2014 Sb., ze dne 19. září 2014, kterou se mění vyhláška č.441/2013 Sb., k provedení zákona o oceňování majetku (oceňovací vyhláška). In Sbírka zákonu, Česká republika. 2008.

Dokládalová, B. (2005) Problematika závislosti nájemného na obvyklé ceně bytu, Soudní inženýrství, vol. 16, pp. 127-144.

Douglas, S. \& Osborn, S. (2014) Property Valuation: The Five Methods. 3rd edition. London: Routledge. ISBN 978-0415717687.

Gelbtuch, H.C. (2011) Real Estate Valuation in Global Markets. 2nd edition. Chicago: Appraisal Institute Chicago, ISBN: 978-1-935328-12- 4.

Janasová, E. \& Slavata, D. \& Ardielli, J. (2014) Specifikace míry kapitalizace vybraného segmentu realitního trhu. Analyticko-statistická studie trhu s byty v Ostravě. 1st edition. Ostrava: VSBTU Ostrava. ISBN 9788024836706.

Komárk, L. \& Kubicová, I. (2011) Methods of identification asset price bubbles in the Czech economy, Politická Ekonomie, vol. 59, iss.: 2, pp. 164-183.

Mackmin, D. (1999) Valuation of real estate in global markets, Property Management, vol. 17, iss: 4, pp. $353-367$.

Maříková, P. \& Mařík, M. (2001) Diskontní míra v oceňování. 1st edition. Praha: VŠE. ISBN 97880-245-0228-3.

Maříková, P. \& Mařík, M. (2007) Diskontní míra pro výnosové oceňování podniku. 1st edition. Praha: Oeconomica. ISBN 978-80-245-1242-6.

Melanda, E. \& Hunter, A. \& Barry, M. (2016) Identification of locational influence on real property values using data mining methods. Cybergeo : European Journal of Geography, [Online], Language version: EN. Available from www: <http://cybergeo.revues.org/27493; DOI : 10.4000/cybergeo.27493>. Consulted: 16.5.2016.

Mills, A.C. \& Parli, R.L. \& Anthony, R. (2008) The valuation of apartment properties. 1st edition. Georgia: Marietta, ISBN 9780922154951.

Parli, R.L. (2008) Apartment Market Analysis, Appraisal journal, vol. 76, no.:1, pp. 60-72.

SREALITY.CZ (2016) Reality a nemovitosti $z$ celé ČR. Available from www: <http://www.sreality.cz/> Consulted: 6.4.2016.

The International Valuation Standards Comitee (2007) International Valuation Standards. Eight Edition. London: IVSC. ISBN 978-0-922154-94-4.

Zazvonil, Z. (2009) Porovnávací hodnota nemovitostí, 1st edition. Praha: EKOPRESS, ISBN 8086929-14-0.

Zazvonil, Z. (1996) Oceňování nemovitostí na tržních principech, 1st edition. Praha: CEDUK, ISBN 80-902109-0-2. 